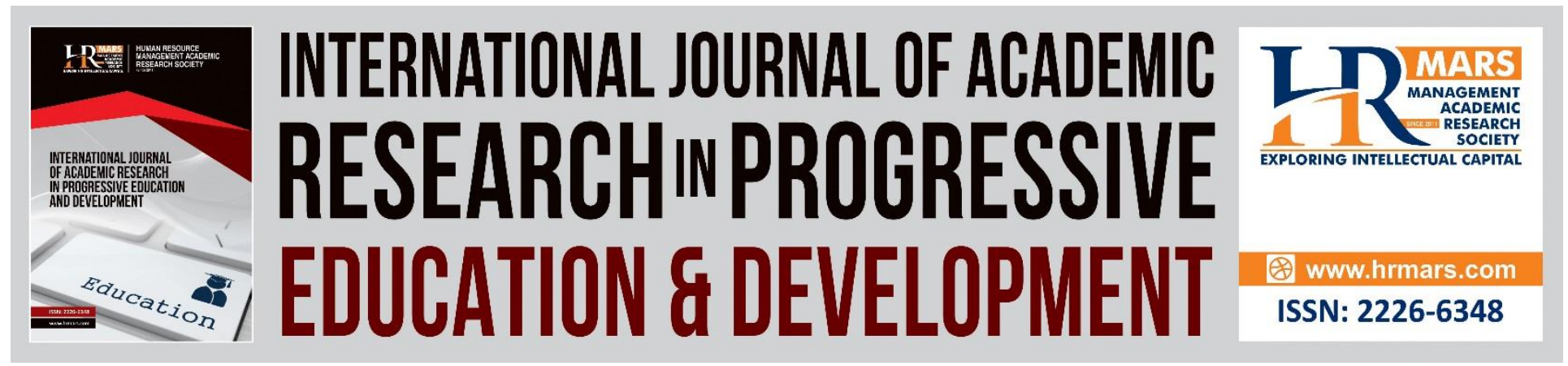

\title{
A New Dimensional in Teaching Non-verbal Students with Learning Disabilities
}

Ahmad Yazid Yahya, Noor Aini Ahmad, Yoong Soo May

To Link this Article: http://dx.doi.org/10.6007/IJARPED/v9-i2/7420 DOI:10.6007/IJARPED/v9-i2/7420

Received: 12 April 2020, Revised: 17 May 2020, Accepted: 14 June 2020

Published Online: 05 July 2020

In-Text Citation: (Yahya et al., 2020)

To Cite this Article: Yahya, A. Y., Ahmad, N. A., \& May, Y. S. (2020). A New Dimensional in Teaching Non-verbal Students with Learning Disabilities. International Journal of Academic Research in Progressive Education and Development, 9(2), 398-407.

Copyright: (C) 2020 The Author(s)

Published by Human Resource Management Academic Research Society (www.hrmars.com)

This article is published under the Creative Commons Attribution (CC BY 4.0) license. Anyone may reproduce, distribute, translate and create derivative works of this article (for both commercial and non-commercial purposes), subject to full attribution to the original publication and authors. The full terms of this license may be seen

at: http://creativecommons.org/licences/by/4.0/legalcode

Vol. 9(2) 2020, Pg. 398 - 407

http://hrmars.com/index.php/pages/detail/IJARPED

JOURNAL HOMEPAGE

Full Terms \& Conditions of access and use can be found at http://hrmars.com/index.php/pages/detail/publication-ethics 


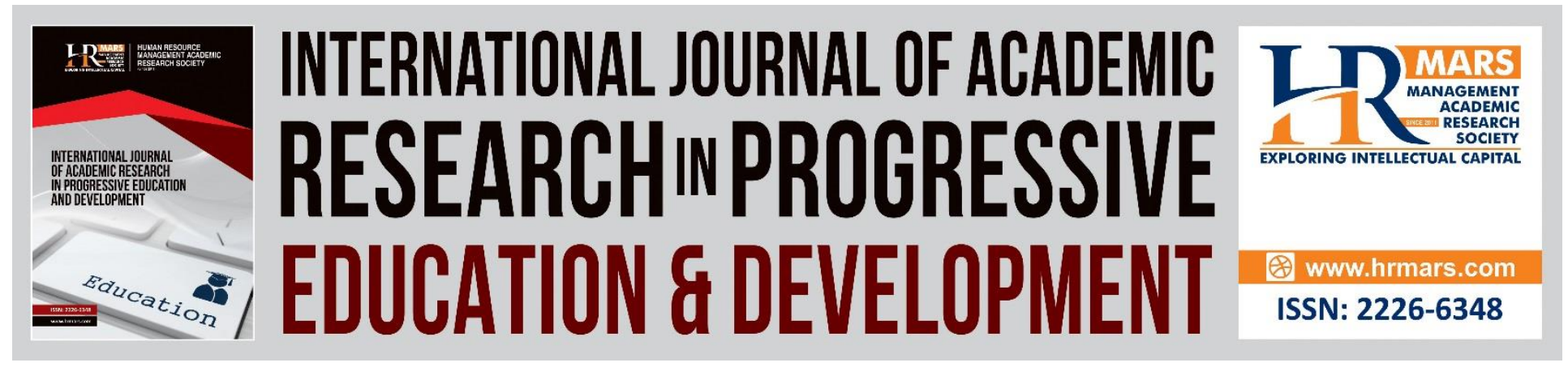

\title{
A New Dimensional in Teaching Non-verbal Students with Learning Disabilities
}

\author{
Ahmad Yazid Yahya, Noor Aini Ahmad, Yoong Soo May \\ Sekolah Kebangsaan Bagan Serai, Special Education Department, Faculty of Human \\ Development, Universiti Pendidikan Sultan Idris, Malaysia, Sekolah Jenis Kebangsaan (Cina) Uk \\ Dih
}

\begin{abstract}
The main aim of this quantitative study is to define the teaching problems among special education teachers in teaching non-verbal students with learning disabilities. Purposive sampling had been used to select 80 participants in this study in Kerian District, Perak. The research instrument used in this study was questionnaire. Descriptive and inferential statistics were used to analyze the data of the study. The findings show that participants faced problems in teaching the non-verbal students with learning disabilities $(M=0.848, S D=0.553)$ and need a teaching module to teach them $(M=0.841, S D=0.672)$. The results of $t$-test showed that no significant between teaching problem with gender of teacher $(P=0.385>0.05, S D=0.330)$. While the results of one-way ANOVA also showed that no significant between teaching problem with teaching experience $(P=0.297>0.05, S D=1.553)$. In conclusion, the problems among non-verbal students with learning disabilities can be solved through intensive training among teachers and development of teaching module based on augmentative and alternative communication with emphasis on functional words. The implication of the study will enable teachers to improve their teaching ability regardless student disabilities and increase the teaching aids and also will assist non-verbal students with learning disabilities to increase interaction with community members.
\end{abstract} Keyword: Student with Non-Verbal Communication, Augmentative and Alternative Communication, Functional Words, Teaching Problem, Teaching Module.

\section{Introduction}

Government has the responsible to ensure all individual to get a suitable education and to ensure that it became the main policy for national development (The Salamanca Statement, 1994). All individuals including people with disabilities are entitled for a fair of education (World Declaration on Education for All (WDEHA, 1990). The paragraph 34 (1) (b) clearly provided minister the statement to create special education program at special school or any of primary or secondary schools which are thought to be suitable and bring benefits (Akta Pendidikan, 1996 (Akta 550; 2012). There were many ways or methods used in conducting the teaching and learning for students with special education needs either in their own way or based on the 
existing curriculums (Ward, 2014). Special Education Act allows teachers to modify their teaching and learning method, time for activity, subjects and teaching aids in implementing of special education curriculum (Special Education Act, 2013). In process of modification, teachers must be focus on knowledge and skills based on students' ability to a clear and intensive learning (McBride \& Goedecke, 2012; Darwish, Abdo, \& AlShuwaiee, 2018). Hence, education for students with learning disabilities should be given priority and teachers should be able to implement the education policy in a flexible way to ensure every student with learning disabilities had the chance to learn according to their needs and abilities.

\section{Problems Statement}

Problems of students with learning difficulties existed in various types and forms, such as they might have difficulties to understand conversation through facial expressions, body language and tone of speech (McMaster Children's Hospital, 2004). The academicians defined that non-verbal students with learning disabilities has problem mainly in language function due to retardation of brain development (Hahn, 2004). There were around half of the students have problems in language function (McCarney, 2009). These students also face difficulties in understanding new knowledge or theoretical aspects in the curriculum (Feiler \& Watson, 2010).

Augmentative and alternative communication (AAC) is recommended to solve communication problems among non-verbal students with learning disabilities (Yusoff \& Mohamed, 2014). AAC is a set of tools and strategies in various forms such as speech, share of view, text, gestures, facial expressions, touches, sign, symbols, picture or words generating tools (International Society for Augmentative and Alternative, 2014). The AAC method based on signal communication is more appropriate to solve the communication problems among non-verbal students with learning disabilities (Anderson, 2001). The signal communication will stimulate the brain function of language building part, communication and social skills (Johnson, 2012). Signal communication should be taught and applied since pre-school to make sure strengthen of communication skills (Peterson, 2008).

Hence, in order to solve this problem, various aspects have to be taken into account, such as the aspect of teachers and students. Based on previous study, special education teachers faced the problems to handle the issues among the non-verbal students with learning disabilities, especially in the aspects of knowledge and teaching skills. AAC teaching methods based on signal communication are suitable for the students because they can be used without the aids of communication tools. The functional words should be a teaching content to help students in order to deliver their own basic needs. The communication abilities of the non-verbal students with learning disabilities will improve the social interaction between the students with other individuals and their environment.

\section{Non-Verbal Students with Learning Disabilities}

Previous studies found that the problem of non-verbal students with learning disabilities is related to genetic element from the aspect of brain retardation (Antshel \& Khan, 2008). Implication from the inability, the students will face difficulty in reading and are tend to rely on 
the information givers (Landwher, 2008). Besides that, students have difficulties in understanding the environment situations such as element of joke if they were separated from other students (Semrud \& Glass, 2008). Non-verbal students with learning disabilities also do not have the ability to understand the analogy and interpret the behavior in their environment (Schiff, Bauminger \& Telodo, 2009). The previous study found that the non-verbal students with learning disabilities have the ability to process the words in learning, but have a significant different in cognitive function if compared with normal students (Gates, 2009).

Model of Social Facilitation based on combination of social training and interaction structured is a believed to be able to solve the problems among non-verbal students with learning disabilities in social and interaction aspect (Simpson, 2008). Approaches of music, dance or singing are suggested to convey their intentions or feelings especially for autism students (Sterland, 2013). In addition, the approach of low-tech teaching aids such a flash card will also helping students to master in the communication skills (Ahmad, 2010). Phone-graphic method, which is the combination of sound and picture, is also able to communicate (Cowden, 2010). Element of picture in communication learning will improve their interaction and communication skills to peers or individuals in their environment (Malone, Fant \& Tullis, 2010). Application of picture element can give a quick and deep impact (Ruppar, Dymond \& Gaffney, 2011).

Other than picture, non-verbal students with learning disabilities can also learn communication skills through signals communication (Ahmad, Mahamod \& Aziz, 2012). Signal communication is a bridge and good foundation to be taught to non-verbal students with learning disabilities (Toth, 2009). The teaching of signal communication has been used in West since more than 30 years ago (Anderson, 2001). Signal communication will provide students with a form of communication which is faster for the parents who have children with limited communication skills (Berke, 2009). Signal communication can stimulate the brain function, which play a role in language building, communication and social skills (Johnson, 2012).

Thus, the problem of non-verbal students with learning disabilities is due to the language system development problems caused by neurological development retardation. Inability of communication skills effects the social interaction development between students with individuals in their environment. Based on the previous study, many researchers had focus on the aspect of social interaction development. Hence, in order to solve the problems among nonverbal students with learning disabilities, various elements such as materials, method, learning content, types of communication, ability to master and student ability to apply the type of communication in their environment must be considered. The combination of audio and visual techniques should be applied and used together in order for the students to master and understand the learning.

\section{Methodology}

This study is a quantitative study using survey method that had been carried out on 80 special education teachers in Kerian District, Perak. The participants were selected based on random sampling. Table 1 shows the participants in terms of gender and experience of teaching. 
Vol. 9, No. 2, 2020, E-ISSN: $2226-6348$ @ 2020 HRMARS

Table 1

Demography Information of Participants

\begin{tabular}{|c|c|c|c|c|c|c|c|c|}
\hline \multirow{2}{*}{ No. } & \multirow{2}{*}{ Gender } & \multicolumn{2}{|c|}{ Total } & \multicolumn{5}{|c|}{ Teaching Experience (Year's) } \\
\hline & & (n) & $\%$ & $<1$ & $1>5$ & $5>10$ & $10>15$ & $15>$ \\
\hline 1. & Male & 21 & 26.2 & 1 & 11 & 9 & & \\
\hline \multirow[t]{2}{*}{2.} & Female & 59 & 73.8 & 5 & 25 & 19 & 7 & 4 \\
\hline & Total & 80 & 100 & 6 & 36 & 28 & 7 & 4 \\
\hline
\end{tabular}

This survey used a questionnaire with validity value $(M=0.79)$ and reliability value (alpha=0.772). The questionnaire contains of a six part, (1) demography, (2) teaching and learning problems, (3) the need of module development, (4) method and module content, (5) module design, and (6) suggestion. All the data were analyzed based on descriptive analysis statistics such percentage and mean, and inferential statistics analysis such a $t$-test, one-way ANOVA and Pearson Correlation. There are four research questions and three null hypotheses (Ho) that represented the second to fourth research questions as follow:

1. What is the level of teaching problems and module needs for teaching and learning of non-verbal students with learning disabilities among special education teacher?

2. Is there any significant difference in teaching problems between genders of special education teacher?

3. Is there any significant difference between teaching problems and teaching experiences of special education teacher?

\section{Results}

The findings were analyzed based on percentage and mean for the first questions, $t$-test analysis for the second questions and Ho1, one-way ANOVA analysis for the third research question and Ho2, and Pearson Correlation for the fourth research questions and Ho3. The findings of research questions and hypotheses showed in form of tables and figures.

\section{First Question}

Table 2 shows the means of analysis for teaching problems and module needs. The table shows the level of teaching problems among special education teacher $(M=0.848, S D=0.553)$ and module needs ( $M=0.841, S D=0.672$ ). This means the special education teacher faced problems in teaching and learning and teaching module for teaching non-verbal students with learning disabilities is needed. 
INTERNATIONAL JOURNAL OF ACADEMIC RESEARCH IN PROGRESSIVE EDUCATION AND

DEVELOPMENT

Vol. 9, No. 2, 2020, E-ISSN: $2226-6348$ @ 2020 HRMARS

Table 2

The Mean Average of Teaching Problems and Module Requirements

\begin{tabular}{clccc}
\hline No. & \multicolumn{1}{c}{ Construct } & Score & Means & Sd \\
\hline 1. & The Teaching Problems Among Teachers & 4371 & 0.848 & 0.553 \\
2. & Needs of Teaching Module & 3734 & 0.841 & 0.672 \\
& Total Average & $\mathbf{4 0 5 2 . 5 0}$ & $\mathbf{0 . 8 4 5}$ & $\mathbf{0 . 6 1 3}$ \\
\hline
\end{tabular}

\section{Second Question}

Table 3 shoes the $t$-test results for Ho1, which have no significant difference for teaching problems between the genders of special education teacher. The test is said to be significant when the probability of $p$ value is less than alpha value $(\alpha)$. The table shows for male $(M=55.048$, $S D=2.747)$, while for female $(M=54.492, S D=2.417)$. The difference between them $(M=0.556$, $\mathrm{SD}=0.330)$. The results showed the significant levels for alpha $(\alpha)$ is $0.385>0.05$. Hence, the results showed that Ho1 is accepted.

Table 3

$T$-test Analysis for Teaching Problem between Genders

\begin{tabular}{clccccc}
\hline Variable & Gender & Mean & $\begin{array}{c}\text { Standard } \\
\text { Division }\end{array}$ & $\begin{array}{c}\text { DK } \\
(\mathbf{n}-\mathbf{2})\end{array}$ & Value-t & Value-p \\
\hline \multirow{2}{*}{ Teaching Problems } & Male & 55.048 & 2.747 & & & \\
& & & & 78 & 0.873 & $0.385^{*}$ \\
& Female & 54.492 & 2.417 & & & \\
\hline
\end{tabular}

Significant of alpha $(\alpha)$ value $=0.05^{*}$

\section{Third Question}

Table 4 shows the results of one-way ANOVA for Ho2, that have no significant difference for teaching problems between teachings experiences of special education teacher. The test is said to be significant when the probability of $p$ value is less than alpha value $(\alpha)$. The table shows that there has no significant difference for the value of $f(4.75)=1.251, p(0.385>0.05)$. Hence, the results of the test showed that $\mathrm{Ho} 2$ is accepted.

Table 4

One-way ANOVA Analysis between Teaching Problems and Teaching Experiences

\begin{tabular}{lccccc}
\hline \multicolumn{1}{c}{ Teaching Problem } & $\begin{array}{c}\text { Sum of } \\
\text { Squares }\end{array}$ & DK & Mean Square & Value $f$ & Value $p$ \\
\hline Between Groups & 30.938 & 4 & 7.734 & 1.251 & $0.297^{*}$ \\
Within Groups & 463.550 & 75 & 6.181 & & \\
Total & 494.488 & 79 & & & \\
\hline
\end{tabular}

$* p<0.05$ 


\section{Discussion}

\section{Problems of Handling and Conducting Teaching}

The existence of non-verbal students with learning disabilities in special education programs is a minority situation, but this does not mean that their presence is negligible (Ahmad, 2010). The findings of the surveys are in line with the studies of Ahmad, Mahamod and Aziz (2012) which found that special education teachers faced problems in handling and conducting teaching for non-verbal students with learning disabilities $(M=0.848, S D=0.553)$. The analysis of $t$-test showed that these is no significant difference of teaching problems between genders of special education teacher $(P=0.385, S D=0.330)$. This means that special education teachers faced problems in handling and conducting teaching to non-verbal students with learning disabilities regardless of the genders. This result of this study is in line with the findings by Ong, Mahamod and Yamat (2013) which examined the relationship between gender and intelligence factors for individuals. The evaluation of gender should be taken into account, because the genders can influence individual in action or face an issue especially involving the election (Misran, Syed Sahuri, Arsad, Hussain, Abd Aziz \& Zaki, 2012).

The results of one-way ANOVA analysis also found that there is no significant difference between teaching problems and teaching experiences $(P=0.297, S D=1.553)$. This means the problem when addressing and conducting the teaching for the non-verbal students with learning disabilities faced by teachers regardless of whether more or less of teaching experiences. The research is done on the aspect of teaching experiences because it can provide satisfaction coverage for the targeted group (Ismail \& Abu, 2016). Experience is also a socialization form that can play the important role in determining behavior (Ning Faidah, Harti \& Subroto, 2018) .The finding is consistent with the survey done by Syed Ali, Abdul Rauf and Salimin (2017) that found that there is no correlation between teaching experience and teaching planning which is the factor that contributes to the teaching problems. However, Abdullah (2018) found that there is a significant relationship between teaching experience and teaching competence of a teacher.

The results based on mean score showed that there are three main factors that contributed to the problem of handling and conducting teaching to the non-verbal students with learning disabilities. The findings showed that the exposure course is a most important element $(M=0.968)$, the knowledge of teaching methods $(M=0.938)$ and the teaching planning $(M=0.900)$. These three main factors are interrelated because exposure courses can provide the knowledge of teaching methods and help teachers to plan the appropriate teaching. The lack of knowledge will cause teachers to have low self-esteem, static and can lost student's beliefs to teachers (Tamuri \& Ajuhary, 2010). The teachers are not only responsible in delivering knowledge to students but also responsible in improving their knowledge and appreciation the learning (Tamuri, Ismail \& Jasmi, 2012).

Based on study by Yahaya, Samsuddin, Mat Jizat and Krishnan (2017) they found that the courses or training had a positive relationship with the teacher's self-efficacy, which refers to the teachers' confidence in implementing actions to achieve the goal or efficiency. Sugumarie and 
Abdul Razak (2014) also found that there is a relationship between the course and training with the improvement of teaching professionalism.

\section{Recommendations and Conclusions}

Based on the analysis, genders and teaching experiences do not influence the level of teaching problems. In order to address that issue, it is recommended that special education teachers should modify or construct and reproduce learning materials, especially low technology teaching aids as flash cards that are appropriate to the needs and capabilities of students such. Secondly, special education teachers should be given exposure through short or regular courses, to ensure that they are more willing to address the problems of non-verbal students with learning disabilities. Constructing the module within concepts of AAC method based on signal communication and teaching content based on functional words should be developed to help teachers to carry out appropriate teaching and learning for non-verbal students with learning disabilities. Through development of module, the problems among the teachers and students will be handled together. The implementation of signal communication to replace the oral communication is able to provide opportunities for non-verbal students with learning disabilities in enhancing the ability to communicate and interact between students and individuals in their social environment.

\section{References}

Abdullah, Z. K. (2015). Pengaruh pengalaman mengajar, iklim kerja dan kompensasi terhadap kompetensi profesional guru di SMK Kristen Salatiga. Disertasi untuk ljazah Sarjana Pendidikan. Semarang, Universitas Negeri Semarang.

Ahmad, N. A., Mahamod, Z., \& Aziz, Z. (2012). Kemahiran komunikasi bagi murid-murid bermasalah pembelajaran teruk. Jurnal Pendidikan Bahasa Melayu, 2(2), 11-18.

Akta Pendidikan 1996 (Akta 550). (2012). Peraturan-peraturan \& kaedah-kaedah terpilih. Putrajaya, Malaysia: International Law Book Services.

Ali, S. K., Abdul Rauf, P., \& Salimin, N. (2017). Hubungan antara pengalaman mengajar dan perancangan pengajaran dalam kalangan guru pendidikan jasmani tingkatan 4. International Journal of Education, Psychology and Counseling. 2(6), 268-277.

Anderson, A. A. (2001). Augmentative communication and autism: A comparison of Sign Language and the picture exchange communication system. Doctoral Dissertation: University of California.

Antshel, K. M., \& Khan, F. M. (2008). Is there an increased familial prevalence of psychopathology in children with nonverbal learning disorders? Journal of Learning Disabilities, 41(3), 208217.

Berke, J. (2009). Sign language - Nonverbal users: Who else uses sign language. Dari laman sesawang: http://deafness.about.com/cs/signfeats1/a/nonverbal \.htm . Tarikh capaian: 25 Mei 2014.

Darwish, S., Abdo, H., \& AlShuwaiee, W. M. (2018). Opportunities, challenges and risks of transition into renewable energy: the case of the Arab Gulf Cooperation Council. International Energy Journal, 18(4). 
INTERNATIONAL JOURNAL OF ACADEMIC RESEARCH IN PROGRESSIVE EDUCATION AND

DEVELOPMENT

Vol. 9, No. 2, 2020, E-ISSN: $2226-6348 @ 2020$ HRMARS

Feiler, A., \& Watson D. (2010). Involving children with learning and communication difficulties: The perspectives of teacher, speech and language therapists and teaching assistant. British Journal of Learning Disabilities, 39(2), 113-120.

Gates, L. L. (2009). Executive function and false recall in nonverbal learning disability. Doctoral Dissertation: York University Toronto.

International Society for Augmentative and Alternative Communication (ISAAC) (2014). What is AAC. Dari laman sesawang: https://www.isaac-online.org/english/what-is-acc/. Tarikh capaian: 28 Mac 2014.

Ismail, H., \& Abu, M. S. (2016). Pengaruh aspek pengalaman ekopelancongan terhadap jangkauan kepuasan pelancong di Malaysia: Kajian kes Melaka. Malaysian Journal of Society and Space, 12(8), 100-109.

Johnson, T. (2012). Important of sign language in children with learning disabilities. Dari laman sesawang: http://www.thelanguagebear.com/ importance-of-sign-language-in-childrenwith-learning-disabilities/. Tarikh capaian: 28 Mac 2014.

Landwher, D. N. (2008). Characteristic patterns of nonverbal learning disabilities: WISC-IV manifestations. Doctoral Dissertation: Widener University.

Malone, H. H. I., Fant, J. L., \& Tullis, C. A. (2010). Using the picture exchange communication system to increase the social communication of two individuals with severe developmental disabilities. Journal of Development \& Physical Disabilities, 22, 149-163.

McBride, H., \& Goedecke, M. (2012). Curriculum modification: Making standart accessible for deaf students with disabilities. New Directions in Deaf Education, 13, 8-11.

McCartney, P. O. (2009). Teaching non-verbal children with autisme to request desired items using single signs. Doctoral Dissertation: Arizona State University.

McMaster Children's Hospital. (2004). Helping your child with non-verbal learning disabilities. Hamilton Health Sciences.

Misran, N., Sahuri, S. N., Arsad, N., Hussain, H., Abd Aziz, N., \& Zaki, W. M. D. (2012). Pengaruh gender terhadap pemilihan program pengajian kejuteraan dalam kalangan pelajajar matrikulasi di Malaysia. Jurnal Pendidikan Malaysia, 37(2), 29-34.

Faidah, N. H., \& Subroto, W. T. (2018). Pengaruh pengalaman ekonomi, control diri serta pendapatan siswa terhadap perilaku ekonomi siswa SMA di Kecamatan Pasir Belengkong Kabupaten Paser. Jurnal Ekonomi Pendidikan dan Kewirausahaan, 6(1), 59-82.

Ong, S. C., Mahamod, Z., \& Yamat, H. (2013). Faktor jantina, kaum, aliran kelas dan hubungannya dengan kecergasan emosi murid dalam mempelajari Bahasa Melayu. Jurnal Pendidikan Bahasa Melayu. 3(1), 12-23.

Peterson, L. (2008). The use of sign language to help austistic children communicate. Dari laman sesawang: http://www.lifeprint.com/asl101/ topics/autism02.htm. Tarikh capaian: 28 Mac 2014.

Prentke Romich Company. (2014). What is augmentative and alternative communication? Dari laman sesawang: https://www.prentrom.com/what-is-augmentative-and-alternativecommunication. Tarikh capaian: 02 April 2014.

Ruppar A. L., Dymond, S. K., \& Gaffney, J. S. (2011). Teachers' perspectives on literacy instruction for students with severe disabilities who use augmentative and alternative communication. Research and Practice for Person with Severe Disabilities, 36(3), 100-111. 
INTERNATIONAL JOURNAL OF ACADEMIC RESEARCH IN PROGRESSIVE EDUCATION AND

DEVELOPMENT

Vol. 9, No. 2, 2020, E-ISSN: $2226-6348$ @ 2020 HRMARS

Schiff, R., Bauminger, N., \& Toledo, I. (2009). Analogical problem solving in children with verbal and nonverbal learning disabilities. Journal of Learning Disabilities, 42(1), 3-13.

Semrud, M., \& Glass, K. (2008) Comprehension of humor in children with nonverbal learning disabilities, reading disabilities, and without learning disabilities. The International Dyslexia, 58(2), 163-180.

Simpson, L. A. (2008). Social facilitation as a clinical intervention for children with nonverbal learning disabilities and asperger's disorder: A theory review. Doctoral Dissertation: Alliant International University.

Special Education Act, (2013). Warta Kerajaan Persekutuan, (2013). Peraturan-peraturan pendidikan (Pendidikan khas). Putrajaya, Malaysia: Jabatan Peguam Negara.

Sterland, E. (2013). 23 ways to communicate with a non-verbal child. Dari laman sesawang: http://www.friendshipcircle.org/blog/2013/04/16/23-ways-to-communicate-with-anon-verbal-child/. Tarikh capaian: 31 Mac 2014.

Sugumarie, S. N. A., \& Abdul Razak, A. Z. (2014, Oktober). Aspek kesesuaian latihan dalam perkhidmatan dan hubungannya dengan peningkatan profesionalisme keguruan. Dalam persidangan: Konvensyen Kebangsaan Penddikan Guru. Malaysia: Seremban.

Tamuri, A. H., \& Ajuhary, M. K. A. (2010). Amalan pengajaran guru pendidikan Islam berkesan berterapkan konsep. Journal of Islamic and Arabic Education, 2(1), 43-56.

Tamuri, A. H., Ismail, M. F., \& Jasmi, K. A. (2012). Komponen asas untuk latihan guru pendidikan Islam. Global Journal Al-Thaqafah, 2(2), 53-63.

The Salamanca Statement and Framework for Action on Special Need Education. (1990). Dalam World Conference on Special Education: Access and Quality. Spain: Salamanca.

World Declaration on Education for All and Framework for Action to Basic Learning Needs. (1990). Dalam World Conference on Education for All Meeting Basic Learning Needs. Thailand: Jomtien.

Yahaya, R., Samsuddin, N., Jizat, M. J. E., \& Krishnan, H. (2017). Hubungan antara latihan dalam perkhidmatan dan efikasi kendiri guru. International Journal of Education, Psychology and Counseling. 2(6), 34-45.

Yusoff, A., \& Mohamed, C. R. (2014). Masalah pembelajaran: Tanda dan simtom kecacatan komunikasi lisan murid pendidikan khas. Jurnal Bahasa, 14(2), 301-324.

Ahmad, N. A. (2010, November). Penggunaan komunikasi augmentatif dan alternatif dalam persekitaran murid bermasalah pembelajaran tanpa komunikasi. Dalam Persidangan: International Conference on Minority and Majority: Language, Culture and Identity. Malaysia: Sarawak. 